\title{
Party Systems in Muslim Societies
}

\author{
Elizabeth R. Nugent*
}

This version: September 2, 2020

\begin{abstract}
Are party systems in Muslim majority societies different from those in non-Muslim majority societies? If so, how - and more importantly, why? Cross-national time-series data demonstrate that party systems in Muslim majority countries are consistently less competitive, less open, and less institutionalized than party systems in non-Muslim majority countries. This chapter synthesizes existing theories of party system formation to argue that the traits of party systems in Muslim majority countries are better explained by both shared experiences and systematic variation in historical developments related to colonialism and the path dependence of institutions, rather than by the political institutions prescribed by Islamic culture. The chapter concludes by outlining a series of unanswered questions about the differences between party systems in Muslim and non-Muslim majority societies.
\end{abstract}

Key words: Muslim Majority Societies, Party Systems, Religion and Politics, Post-Colonialism

Pre-publication version of chapter for

Oxford Handbook of Politics in Muslim Societies, ed. Melani Cammett and Pauline Jones, 2021.

• Assistant Professor, Department of Political Science, Yale University. Contact: elizabeth.nugent@yale.edu. 
This chapter explores whether and how existing theories of party system formation can help us to understand the institutions that have developed in Muslim majority societies. I ask the following questions: Are party systems in Muslim majority and non-Muslim majority societies systematically different from each other? If so, how - and more importantly, why? I rely on cross-national time-series data of party systems and draw on the rich literature on politics in the Muslim world to answer these questions. The data demonstrate that party systems in Muslim majority countries are consistently less competitive, less open, and less institutionalized - though I note important exceptions located in Muslim democracies.

I argue that the traits of party systems in Muslim majority countries are better explained by specific historical developments in the Muslim world and the path dependence of party system institutions, rather than by the political institutions prescribed by Islamic culture. More specifically, patterns of governance and institutions adopted by European authorities during colonialism coincided with a consequential period of state building in the Muslim world, and this in turn shaped the rules of the game in post-colonial countries. This finding is not unique to Muslim majority societies; scholars have made similar arguments about post-colonial political institutions in other parts of the world, with variation produced through the nature, timing, and duration of the colonial experience. I conclude the chapter by outlining remaining questions about party systems in Muslim majority societies that might shape a research agenda on the topic.

\section{Defining and Measuring Party Systems}

The study of parties, and the systems in which they are organized, are central to the study of politics. Drawing from the experience of early democratizing countries in Western Europe, scholars reached a normative consensus that parties are of the utmost importance in democratic politics (White 2006, 5-15). As democracy spread beyond Europe, political scientists employ measurements of the emergence of party competition as a proxy for successful democratization. Scholars continue to deem parties "absolutely essential for the proper functioning of representative democracy" (Montero 2003, 3).

Parties represent collective interests in political competition: in politics, "no idea has ever made much headway without an organization behind it" (Sartori 1976, 85). In their idealized form, parties simply reflect the shared, aggregated political preferences of its constituent members: they "crystallize and make explicit the conflicting interests, the latent strains and contrasts in the existing social structure" (Lipset and Rokkan 1967, 3). But in practice, parties exert influence on the creation and nature of collective interests. Parties have agency in choosing which constituencies to mobilize and under what banner, and in this way can exert influence on the dimensions of political contestation. The political relevance of "class, ethnicity, religion, race or nation do[es] not happen simultaneously... as a reflection of the objective conditions in the psyches of individuals" (Przeworski 1985, 99-101). Instead, parties may "establish themselves as significant poles of attraction and produce their own alignments independently of the geographical, the social, and the cultural underpinnings of the movements" (Lipset and Rokkan 1967, 3). Neto and Cox (1997) similarly argue that "politicians can take socially defined groups and combine or recombine them in many ways for political purposes."

Parties are a function of the broader political context in which they exist. The amorphous concept of a party system refers to the interaction of parties competing with each other within a given country. ${ }^{1}$

\footnotetext{
${ }^{1}$ See Herbert Kitschelt, "Party Systems" in Oxford Handbook of Comparative Politics, eds. Carles Boix and Susan C. Stokes (Oxford University Press, 2007), 522-554 for an extensive review.
} 
Scholars rely less on a clear definition of party systems and instead used different criteria to identify and compare different types. Duverger (1954) first discussed the importance of the interactions between parties as part of a larger system, in order to understand the relative options offered to voters within a given context. In addition to the characteristics of individual parties, he noted that it is important to consider the "numbers, respective sizes, alliances, geographical localization, [and] political distribution" of parties competing with each other within the same political space. As the result of this interactive process, "a party system is defined by a particular relationship amongst all these characteristics."

Party systems are measured by several distinct attributes. These include the number of parties contesting elections and the number of effective parties, or parties that actually win seats in government (Blondel 1968; Laasko and Taagepera 1979; Siaroff 2000). Party systems can also be categorized by the relative size, strength, and balance of parties (Rokkan 1970; Wolinetz 2006). Party systems also differ on the distribution and polarization of parties, measured by the distance separating parties on salient axes of contestation and in affect. ${ }^{2}$ In addition, party systems differ in the degree to which competition for government is open or closed - meaning, whether all parties can enter elections without any constraints or whether contestation is restricted only to certain parties or combinations of parties (Mair 1996, 2002). In terms of linkages with voters, party systems may revolve around programmatic, ideological, clientelist, or charismatic competition (Kitschelt et al. 1999, 2010). The nature of competition within a given party system determines the degree to which it is institutionalized and structures the electorate (Mainwaring and Scully 1995; Mainwaring 1999).

These measurements help us characterize and compare party systems. The criterial approach to defining and measuring party systems bridges the divide across regime types, linking democratic and authoritarian systems on a spectrum of competition and institutionalization.

\section{Comparing Party Systems in Muslim and Non-Muslim Majority Societies}

Are party systems in Muslim-majority and non-Muslim majority societies different? And if so, in what ways? To unpack this, I turn to data from the Varieties of Democracy (V-Dem) project (Coppedge et al. 2020). V-Dem is an ideal dataset to use for my analyses because it includes an extensive set of indicators capturing different aspects and dimensions of party systems as well as important correlates. In addition to aggregate scores measuring a party system's level of competitiveness or democratic quality, the dataset includes fine-grained constitutive measurements capturing indicators central to comparing party systems such as the number and relative strength of effective parties, the distribution of parties on salient axes of competition, and the nature of voter-party linkages. Moreover, the project's expansive country and temporal coverage is helpful for measuring trends and differences in party systems across time and space. I subset version 10 of the V-Dem dataset from 1900 on and separate countries with Muslim-majority populations to those without a majority Muslim population. The charts plot the raw data as well as fit lines, indicating trends in the data. All data has been recoded so that the plots read as more "democratic"

\footnotetext{
${ }^{2}$ For studies of preference polarization, see Giovanni Sartori, Parties and Party System: A Framework for Analysis (Harvard University Press, 1976); Alan Ware, Political Parties and Party Systems (Oxford University Press, 1996); Peter Mair, "Comparing Party Systems" in Comparing Democracies 2: New Challenges in the Study of Elections and Voting, eds. Lawrence LeDuc, Richard G. Niemi and Pippa Norris (Sage: 2002), 88-107. For studies on affective polarization, see Shanto Iyengar, Yphtach Lelkes, Matthew Levendusky, Neil Malhotra, and Sean J. Westwood, "The Origins and Consequences of Affective Polarization in the United States." Annual Review of Political Science 22 (2019): 129-146; Elizabeth R. Nugent, After Repression: How Polarization Derails Democratic Transition (Princeton University Press, 2020).
} 
(with specific meaning depending on the index or variable) as the $y$-axis approaches 1 . The $x$-axis measures year.

Two indices demonstrate how party systems in Muslim majority societies differ from those in non-Muslim societies. For each index, individual components trend the same way as the index, with some variation in the degree of difference between party systems in Muslim and non-Muslim majority societies, though not the level of significance. The first index, electoral democracy combines a number of subcomponents measuring the openness and level of competition of party systems. The index ranges from 0 to 1 , with a higher score indicating more clean, fair, and competitive electoral institutions. The index combines measurements of freedom of expression, universal suffrage, and frequency of voting irregularities. In addition, the index includes a measurement of freedom of association, which captures whether parties are banned, what if any barriers exist to party entry into electoral competition, the level of autonomy of opposition parties, and whether multiparty elections occur. The index also includes a component capturing pluralism in elected officials holding office, similar to the idea of effective parties outlined in the previous section.

Figure 1 demonstrates that all party systems become more open, inclusive, and competitive over time. However, party systems in non-Muslim majority countries consistently score higher than those in Muslim majority countries, suggesting they are relatively more open to competition, more competitive, and fairer in that competition. The gap between party systems in the two groups of countries is persistent but appears to increase starting in the 1970s.

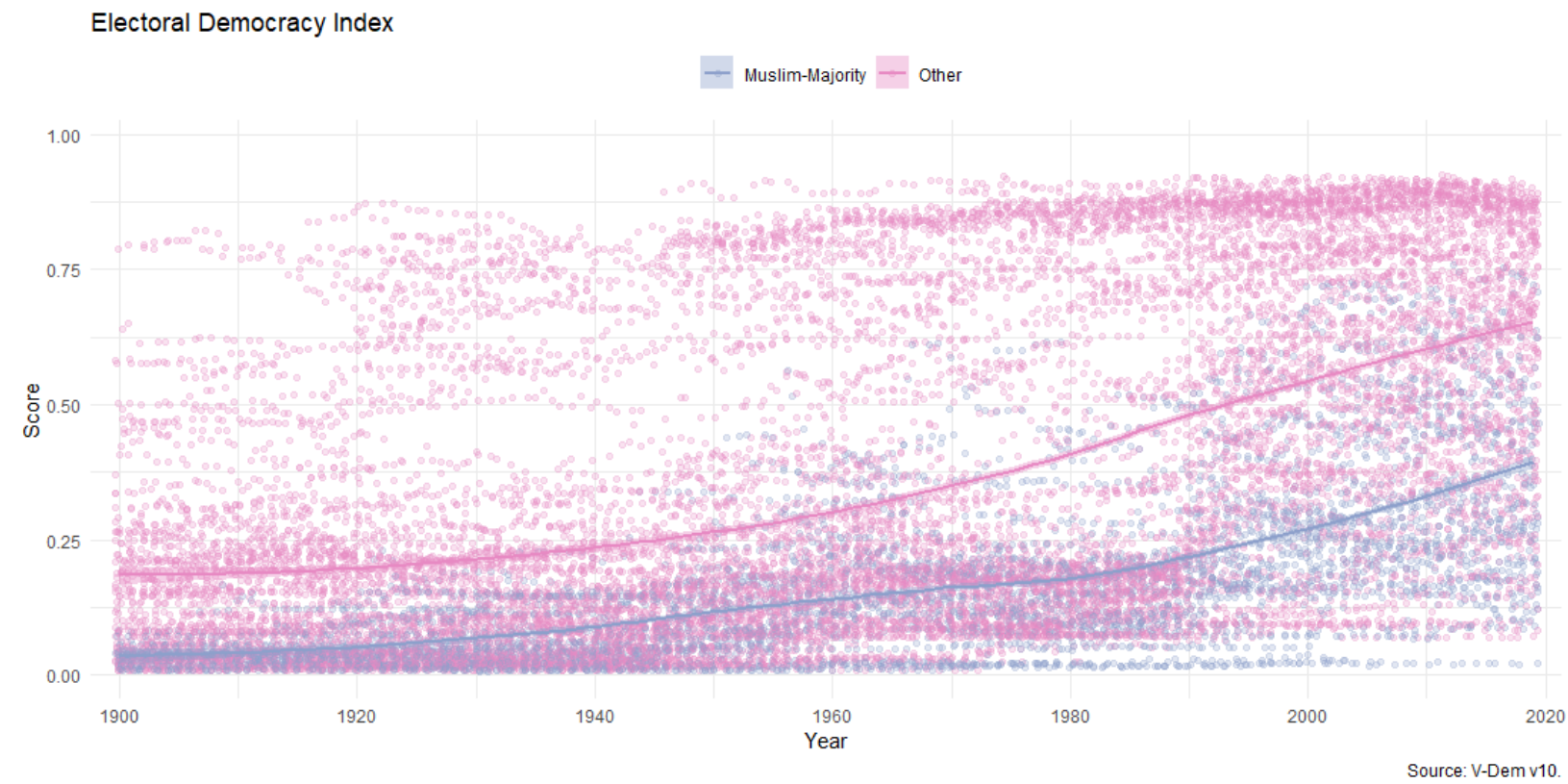

Figure 1. Electoral Democracy, 1900-2019

The second index, party institutionalization, combines a number of subcomponents measuring the balance and function of parties within a given system. The index ranges from 0 to 1 , with higher scores indicating a more institutionalized party system that structures political competition. The index includes measurements of the level and depth of party organization and internal party cohesion in structure, platform, and ideology. In addition, the index includes a measurement capturing the extent to which 
party platforms are distinct from each other. The index also includes a measurement of the nature of voter-party linkages, whether these are clientelist, local collective, programmatic, or mixed between types.

Figure 2 demonstrates that over time, party systems have become more institutionalized. Party systems in non-Muslim majority countries consistently score higher than those in Muslim majority countries, meaning they are more institutionalized. The gap between party systems in the two types of countries is persistent and consistent in size from initial differences over time.

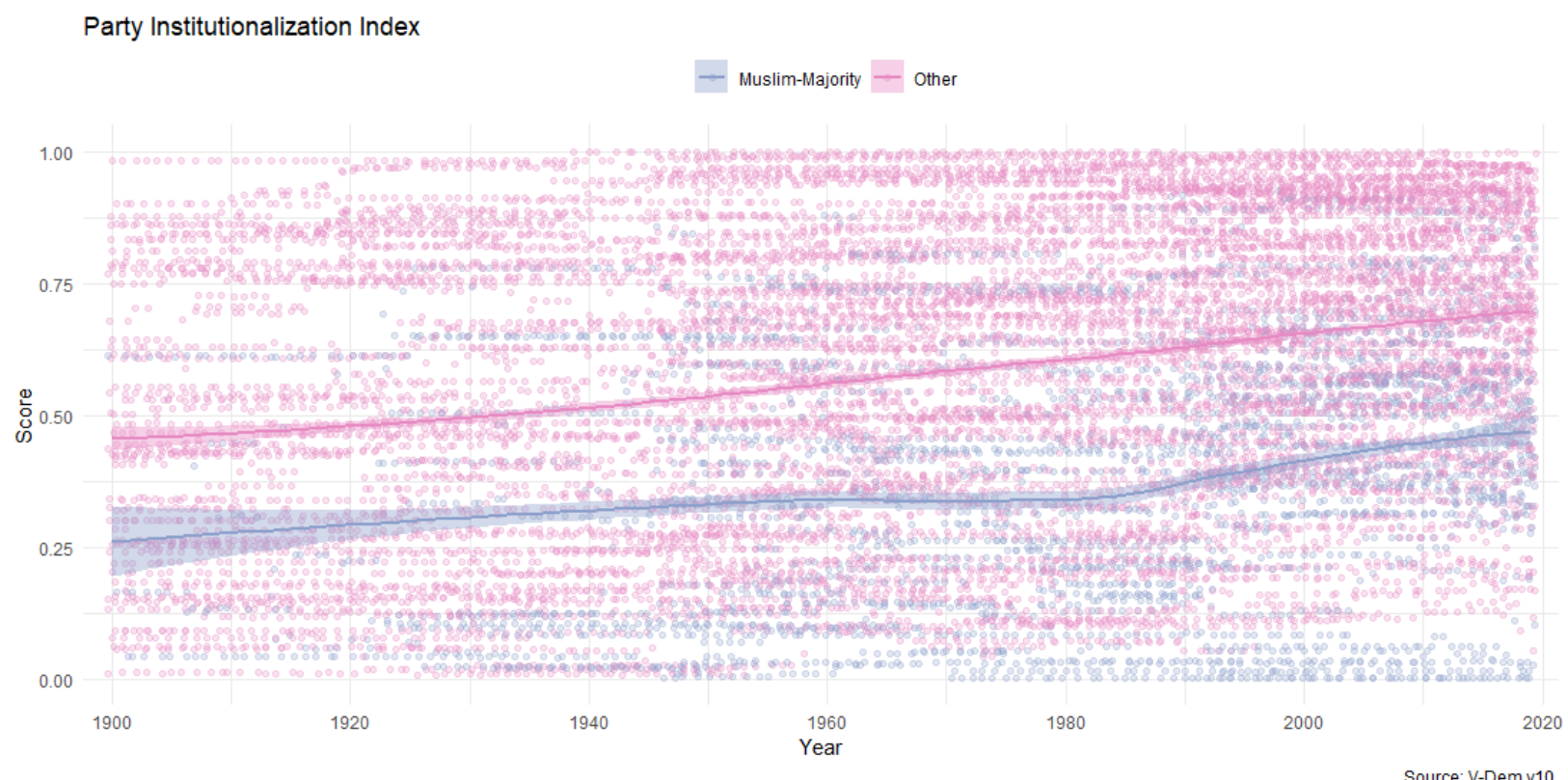

Figure 2. Party Institutionalization, 1990-2019

\section{Sociological Explanations for Party System Divergence}

What helps to explain the persistent differences between party systems in Muslim majority and non-Muslim majority societies? Explanations for how parties and party systems form, and why they differ, fall into two broad categories: sociological or institutional (Boix 2009). Sociological explanations outline a bottom-up process through which societal divisions external to the political system shape the nature and function of political contestation. Underlying factors refer to the demographic distribution along social, political, and economic cleavages. Broader historical processes of nation-building, state consolidation, development, modernization, and industrialization create meaningful underlying divisions among society and variation across societies, which in turn influence party formation, placement, and function (Lipset and Rokkan 1967; Evans and Whitefield 2000; Deegan-Krause 2006; Haggard and Kaufman 2016). Variation in party systems across cases stems from different underlying cleavage structures, and shifts within cases result from the shifting of underlying cleavages (Sigelman and Yough 1978; McCarty, Poole, and Rosenthal 2006; Ura and Ellis 2011; Lupu and Riedel 2013).

How would a sociological explanation account for party system differences in Muslim and nonMuslim majority societies? It would mean that the nature of cleavages in Muslim societies would both explain the initial divergence and the persistent difference from party systems in non-Muslim majority societies. V-dem includes a proxy measurement of polarization of society, asking coders to "characterize the differences of opinions on major political issues," presented in figure 3 . The data is limited from 2000 to 2019, but does not indicate that Muslim and non-Muslim majority societies are differently polarized; 
both, on average, score a medium level of polarization. While the data does not include indicators for the early 1990s, the available contemporary data suggests there is no relationship between societal polarization and party systems.

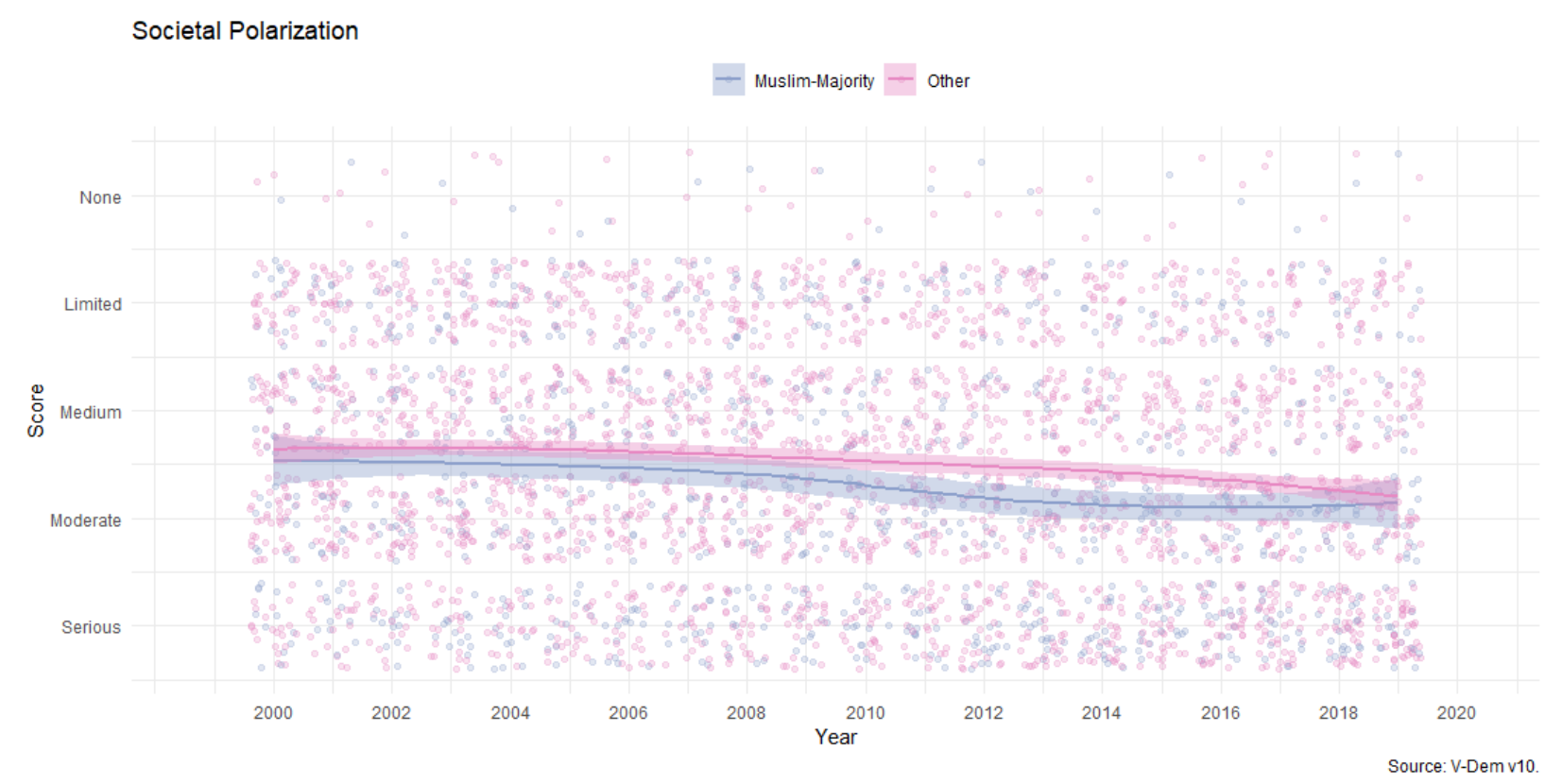

Figure 3. Societal Polarization, 2000-2019

\section{Institutional Explanations for Party System Divergence}

Institutional explanations for party system formation outline a top-down process through which formal institutions adopted shape the nature and function of political contestation (Boix 2009). Most influential are those features which define the internal workings of the political system, primarily electoral rules and institutions. Formal institutions can complicate the translation of underlying interests into political competition, enhance or diminish polarization, and shape what parties compete over by requiring certain thresholds for participation, forcing certain partnerships and patterns of strategic placemen, and distributing public goods based on representation in elected bodies (Cox 1987; Taagepera and Shugart 1989; Shugart and Carey 1992).

How would an institutional explanation account for party system differences in Muslim and nonMuslim majority societies? It would mean that the nature of institutions in Muslim societies would both explain the initial divergence and the persistent difference from party systems in non-Muslim majority societies. Historical institutionalism suggests strong path dependence after an initial critical juncture establishing institutions, so I spend more time theorizing why Muslim societies may have come to possess different kinds of political institutions in the first place.

There are at least two possible ways in which Muslim societies may have come to initially possess certain political institutions. The first is through Islamic culture. Scholars have previously questioned whether the religion of Islam is the reason behind the predominance of authoritarianism in Muslimmajority societies. The focus has largely been on whether Islam prevents the development of democratic citizens, building on the implications of canonical comparative politics texts on political culture such as those by Almond and Verba (1963) and Lipset (1969). Islam and its prescribed behaviors are argued to 
create a culture which is inhospitable to democracy. ${ }^{3}$ While this claim remains influential in academic, policy, and public debates about the Muslim world, it largely lacks empirical support. ${ }^{4}$ Islam may also influence the nature of political institutions through cultural prescriptions. Much debate has revolved around two specific institutions derived from the practices of the Prophet Mohammed and the early Muslim community. The first is shura, translated as consultation. This concept refers to a process of collecting and discussing different opinions on a particular subject in order to reach a decision. The second institution is that of bay $a h$, an oath of allegiance to a leader.

There is no theoretical or empirical consensus that these concepts deterministically translate into institutions lacking democratic qualities. Islam is a discursive tradition and is interpreted and practiced very differently by individuals across time and space (Asad 2002). For example, shura has been argued to both be the basis for the implementation of representative democracy as well as the basis for the tyranny of the majority, a critique notably also levied against secular institutions. Further, both in theory and in practice, Muslim polities have differed in whether consultation occurs with experts, those affected by a decision, or representatives of these groups, resulting in more and less direct representation. Similarly, interpretations of bay ah differ in whether it implies a social contract in which a leader is responsible to and limited by the people he represents, or unquestioning loyalty to a leader in order to prevent disorder and thus inhibits the establishment of institutional checks and balances of executive power (Abou El Fadl 2004; Tezcür 2007). While many party systems in Muslim majority societies demonstrate undemocratic characteristics, there are important exceptions in countries like Indonesia, Malaysia, and Tunisia, all of which host highly competitive and open political systems that include Islamist parties and draw on religious tenets in the constitution, undermining a deterministic relationship between Islam and undemocratic political institutions. Quantitative studies demonstrate that denser and more encompassing Islamic political, educational, and financial institutions correlates with political institutions of higher democratic quality (Achilov 2010).

The second way in which Muslim societies may have come to possess different political institutions is through colonial endowments. This argument rests on a close reading of the historical political development of the Muslim world, with attention paid to when and how party systems emerged, what their initial purpose was, and how this influenced their shape and nature. European colonialism coincided with a consequential period of modern state-building in Muslim majority societies for subsequent patterns of state capacity, the nature of coercive institutions, and economic development. The development projects that significantly shaped the institutions of states in Muslim majority societies were guided by an overarching colonial strategy that favored the interests of the colonizer. In line with their material and strategic interests, colonial powers created or coopted a variety of governance institutions to control local populations and channel dissent rather than to represent and respond to local interests (Anderson 1986; Méouchy and Sluglett 2004; Acemoglu, Johnson, and Robinson 2000). The institutional inheritance with which independent states were endowed shaped post-independence

\footnotetext{
${ }^{3}$ Scholars alternatively point to the strength of [non-nationalist] identities, the creation of docile citizens, and a lack of respect for pluralism, gender equality, and protections for minorities. See Ernest Gellner, Muslim Society. (Cambridge University Press, 1983); Samuel P. Huntington, The Clash of Civilizations and the Remaking of World Order (Simon and Schuester, 1996); Ronald Inglehart and Pippa Norris, Rising Tide: Gender equality and cultural change around the world (Cambridge University Press, 2003).

${ }^{4}$ Public opinion data largely disconfirms the hypothesized relationship between high religiosity and intolerance. See work summarized in Mark A. Tessler, Public opinion in the Middle East: Survey research and the political orientations of ordinary citizens (Indiana University Press, 2011).
} 
institutions in significant ways through mechanisms of path dependence. Party systems were no exception. Foreign colonial powers created legislative institutions that were unrepresentative, promoting certain favored groups integral to colonial rule at the expense of other groups. They also fostered, politicized, and institutionalized certain societal divisions and certain modes of contestation and redistribution that were highly contentious in order to divide and conquer local populations (Laitin 1985; Mamdani 1996; Mahoney 2010).

This institutional inheritance predicts subsequent political institutions. The nature of political institutions at the onset of liberalization accompanying independence from colonialism significantly influenced the creation of electoral rules in the subsequent regime. For example, elites in post-colonial countries which had previously been governed by a single-party system systematically adopted electoral laws that concentrated legislative power in the hands of the dominant party. In contrast, post-colonial countries that had formerly been governed by monarchies under colonialism adopted electoral rules that supported a balance of power among multiple competing forces, in a continued strategy of divide-andconquer. In line with mechanisms of historical institutionalism, incumbents' preferences over the distribution of domestic political power vary across different types of inherited regimes, and this shapes their preferences for the distribution of power in the post-colonial period (Lust-Okar and Jamal 2002).

The legacy of colonialism on party system formation in the Muslim world means that parties are less likely to serve a programmatic function. Parties may also serve distributive, surveillance, and control functions unrelated to representation of collective interests (Hibou 2011; Blackman 2019). As a result, party systems are less open to meaningful competition and less institutionalized in post-colonial periods. While the colonial experience was globally consequential, it was not even or uniform throughout the world let alone the Muslim world. Colonial systems of control differed in the nature and form of the relationship between the colonizer and the colonized well beyond simplistic distinctions between direct and indirect rule (Crowder 1964; Méouchy and Sluglett 2004). And so while colonialism generally undermined the representative and responsive functions of governance institutions, it also produced meaningful variation that is helpful in understanding and measuring its historical effect on subsequent institutions (Ricart-Huguet 2019).

\section{Conclusion}

In this chapter, I have discussed whether, how, and why party systems in Muslim majority countries differ systematically and significantly from those in non-Muslim majority countries. Crossnational, time-series data from $\mathrm{V}$-dem demonstrates that while generally the party systems of the world are liberalizing, including more political interests and becoming more institutionalized, the Muslim world lags behind its non-Muslim counterpart. In my reading of existing literature, this gap is better explained by institutional endowments rather than cultural ones. In thinking about party systems in Muslim majority societies, it is necessary to interrogate the theoretical and practical differences that render party systems in non-democratic regimes fundamentally different from those in democratic contexts. What this means substantively is that scholars of party systems in the Muslim world must recognize that political institutions do not always reflect underlying cleavages or unfettered mobilization of collective interests. Instead, these party systems reproduce inherited methods of control.

Future work on the subject might expand this line of inquiry in at least two important ways. First, how do party systems persist through independence, an event that is often considered a political rupture? Existing scholarship suggests the importance of initial post-independence leaders' idiosyncratic 
preferences for governance and perceptions of political threats. However, we might better understand the persistence of party systems by mapping those state employees and foreign consultants who continue to staff these institutions through independence, as well as the relative balance of power between political interests as similarly shaped by colonial strategies of control.

Second, how might party systems be meaningfully reformed to become more representative, more competitive, and more institutionalized? Neither decades of foreign aid to promote democracy in Muslim majority countries nor countless domestic attempts at mass mobilization and protest demanding democratization have significantly changed the nature of these party systems. However, perhaps in further interrogating the origins and persistence of these party systems, scholars might come up with innovative solutions to overcome the challenges of institutional inheritance. Looking to successful transitions from undemocratic to democratic party systems in Muslim majority societies may shed light on best practices. 


\section{References}

1. Abou El Fadl, Khaled. Islam and the Challenge of Democracy. Princeton University Press, 2004.

2. Daron Acemoglu, Simon Johnson, and James A. Robinson, "The Colonial Origins of Comparative Development: An Empirical Investigation," National Bureau of Economic Research, 2000.

3. Achilov, Dilshod. "Can Islam and Democracy Coexist? A Cross-National Analysis of Islamic Institutions in the Muslim World.” PhD dissertation, University of Arizona, 2010.

4. Almond, Gabriel A. and Sidney Verba. Political Culture: Political Attitudes and Democracy in Five Nations. Princeton University Press, 1963.

5. Anderson, Lisa. The State and Social Transformation in Tunisia and Libya, 1830-1980. Princeton: Princeton University Press, 1986.

6. Asad, Talal. "The Idea of an Anthropology of Islam." Qui parle 17.2 (2009): 1-30.

7. Blackman, Alexandra. "Ideological Responses to Settler Colonialism: Political Identities in PostIndependence Tunisia." Working paper, 2019.

8. Boix, Carles. "The Emergence of Parties and Party Systems" in Oxford Handbook of Comparative Politics, eds. Carles Boix and Susan C. Stokes. New York: Oxford University Press, 2009, 314334.

9. Coppedge, Michael, John Gerring, Carl Henrik Knutsen, Staffan I. Lindberg, Jan Teorell, David Altman, Michael Bernhard, M. Steven Fish, Adam Glynn, Allen Hicken, Anna Luhrmann, Kyle L. Marquardt, Kelly McMann, Pamela Paxton, Daniel Pemstein, Brigitte Seim, Rachel Sigman, Svend-Erik Skaaning, Jeffrey Staton, Steven Wilson, Agnes Cornell, Nazifa Alizada, Lisa Gastaldi, Haakon Gjerløw, Garry Hindle, Nina Ilchenko, Laura Maxwell, Valeriya Mechkova, Juraj Medzihorsky, Johannes von Römer, Aksel Sundström, Eitan Tzelgov, Yi-ting Wang, Tore Wig, and Daniel Ziblatt. 2020. "V-Dem Dataset v10." Varieties of Democracy (V-Dem) Project.

10. Cox, Gary W. The Efficient Secret. New York: Cambridge University Press, 1987.

11. Crowder, Michael. "Indirect rule - French and British style," Africa 34, no. 3 (1964): 197-205.

12. Deegan-Krause, Kevin. "New Dimensions of Political Cleavage" in Oxford Handbook of Political Science, eds. R. Dalton and H.-D. Klingemann. Oxford: Oxford University Press, 2006.

13. Duverger, Maurice. Political Parties. Wiley, 1954.

14. Evans, Geoffrey, and Stephen Whitefield. "Explaining the Formation of Electoral Cleavages in Post-Communist Democracies." Elections in Central and Eastern Europe: The First Wave (2000): 36-70.

15. Gellner, Ernest. Muslim Society. Cambridge University Press, 1983.

16. Haggard, Stephan, and Robert R. Kaufman. "Democratization During the Third Wave." Annual Review of Political Science 19 (2016): 125-144.

17. Hibou, Béatrice. The Force of Obedience. Polity, 2011.

18. Huntington, Samuel P. The Clash of Civilizations and the Remaking of World Order. New York: Simon and Schuester, 1996.

19. Inglehart, Ronald and Pippa Norris. Rising Tide: Gender equality and cultural change around the world. Cambridge University Press, 2003.

20. Iyengar, Shanto, Yphtach Lelkes, Matthew Levendusky, Neil Malhotra, and Sean J. Westwood. "The Origins and Consequences of Affective Polarization in the United States." Annual Review of Political Science 22 (2019): 129-146.

21. Kitschelt, Herbert. "Party Systems" in Oxford Handbook of Comparative Politics, eds. Carles Boix and Susan C. Stokes. Oxford University Press, 2007.

22. Kitschelt, Herbert, Kirk A. Hawkins, Juan Pablo Luna, Guillermo Rosas, and Elizabeth J. Zechmeister. Latin American Party Systems. Cambridge: Cambridge University Press, 2010. 
23. Kitschelt, Herbert, Zdenka Mansfeldova, Radoslaw Markowski, and Gabor Toka. Post-Communist Party Systems: Competition, Representation, and Inter-Party Cooperation. Cambridge: Cambridge University Press, 1999.

24. Laakso, Markku, and Rein Taagepera. "Effective number of parties: A measure with application to West Europe." Comparative Political Studies 12:1 (1979): 3-27.

25. Laitin, David. 1985. "Hegemony and Religious Conflict: British Imperial Control and Political Cleavages in Yorubaland.” in Peter Evens et al. (eds.), Bringing the State Back In. Cambridge: Cambridge University Press.

26. Lipset, Seymour M. "Some Social Requisites of Democracy: Economic Development and Political Legitimacy.”American Political Science Review 53, no. 1 (1969): 69-105.

27. Lipset, Seymour M., and Stein Rokkan. "Cleavage Structures, Party Systems, and Voter Alignments: An Introduction" in Party Systems and Voters Alignments: Cross-National Perspectives, eds. Seymour M. Lipset and Stein Rokkan. Free Press, 1967.

28. Lupu, Noam, and Rachel Beatty Riedl. "Political parties and uncertainty in developing democracies." Comparative Political Studies 46.11 (2013): 1339-1365.

29. Lust-Okar, Ellen and Amaney Jamal. "Rulers and Rules: Reassessing the Influence of Regime Type on Electoral Law Formation.” Comparative Political Studies, 35.3 (2002), 337366.

30. Mahoney, James. 2010. Colonialism and Postcolonial Development: Spanish America in Comparative Perspective. Cambridge: Cambridge University Press.

31. Mainwaring, Scott. Rethinking Party Systems in the Third Wave of Democratization: The Case of Brazil. Palo Alto, California: Stanford University Press, 1999.

32. Mainwaring, Scott and Timothy R. Scully. Building Democratic Institutions: Party Systems in Latin America. Stanford, California: Stanford University Press, 1995.

33. Mair, Peter. What is Different about Post-Communist Party Systems? Center for the Study of Public Policy at University of Strathclyde, 1996.

34. Mair, Peter. "Comparing Party Systems" in Comparing Democracies 2: New Challenges in the Study of Elections and Voting, eds. Lawrence LeDuc, Richard G. Niemi and Pippa Norris. Sage: 2002.

35. Mamdani, Mahmood. 1996. Citizen and Subject: Contemporary Africa and the Legacy of Late Colonialism. Princeton, NJ: Princeton University Press

36. McCarty, Nolan, Keith T. Poole, and Howard Rosenthal. Polarized America: The dance of ideology and unequal riches. MIT Press, 2006.

37. Méouchy, Nadine, and Peter Sluglett. The British and French Mandates in Comparative Perspectives (Les Mandats Francais Et Anglais Dans Une Perspective Comparative). Brill, 2004.

38. Montero, Jose Ramon. "Introduction: Reviewing and Reassessing Parties" in Political Parties: Old Concepts and New Challenges, eds. Richard Gunther, Jose Ramon Montero, and Juan J. Linz. Oxford University Press: 2003.

39. Neto, Octavio Amorim and Gary W. Cox. "Electoral Institutions, Cleavage Structures, and the Number of Parties." American Journal of Political Science, 41:1 (1997), 149- 174.

40. Nugent, Elizabeth R. After Repression: How Polarization Derails Democratic Transition. Princeton University Press, 2020.

41. Przeworski, Adam. Capitalism and Social Democracy. Cambridge University Press, 1985.

42. Rokkan, Stein. "Nation-building, cleavage formation and the structuring of mass politics." Citizens, Elections, Parties: Approaches to the comparative study of the processes of development (1970): 72-144.

43. Sartori, Giovanni. Parties and Party System: A Framework for Analysis. Cambridge, Massachusetts: Harvard University Press, 1976.

44. Sartori, Giovanni. "Politics, Ideology, and Belief Systems." American Political Science Review 63:2 (1969), 398-411. 
45. Shugart, Matthew Soberg, and John M. Carey. Presidents and Assemblies: Constitutional Design and Electoral Dynamics. Cambridge: Cambridge University Press, 1992.

46. Siaroff, Alan. Comparative European Party Systems: An Analysis of Parliamentary Elections since 1945. New York: Garland Publishers, 2000.

47. Sigelman, Lee, and Syng Nam Yough. "Left-right Polarization in National Party Systems: A Cross-National Analysis." Comparative Political Studies 11, no. 3 (1978): 355-379.

48. Taagepera, Rein, and Matthew Soberg Shugart. Seats and Votes: The Effects and Determinants of Electoral Systems. New Haven: Yale University Press, 1989.

49. Tessler, Mark A. Public opinion in the Middle East: Survey research and the political orientations of ordinary citizens. Indiana University Press, 2011.

50. Tezcür, Güneş Murat. "Constitutionalism, judiciary, and democracy in Islamic societies." Polity 39.4 (2007): 479-501.

51. Ura, Joseph Daniel, and Christopher R. Ellis. "Partisan Moods: Polarization and the Dynamics of Mass Party Preferences." Comparative Political Studies 74, no. 1 (2011): 277-291.

52. Ware, Alan. Political Parties and Party Systems. New York: Oxford University Press, 1996.

53. White, John Kenneth. "What is a Political Party?" in Handbook of Party Politics eds. William S. Katz and William Crotty. Sage, 2006.

54. Wolinetz, Steven B. "Party Systems and Party System Types." Handbook of Party Politics eds. William S. Katz and William Crotty. Sage, 2006. 